\title{
A Novel Model for analyzing the Effective Factors on the Intention to Use Mobile Banking Apps, Case Study: Iran Mellat Bank
}

\author{
Shirin Karami ${ }^{1}$, Majid Haghparast ${ }^{2 *}$ and Mohsen Gharehkhani ${ }^{3}$ \\ ${ }^{1}$ Department of Computer Engineering, E-Campus, Islamic Azad University, \\ Tehran, Iran \\ ${ }^{2}$ Department of Computer Engineering, Yadegar-e-Imam Khomeini (RAH) Shahre \\ Rey Branch, Islamic Azad University, Tehran, Iran \\ ${ }^{3}$ Department of Financial Engineering, Electronic Institute of Higher Education of \\ Iranian, Tehran, Iran \\ *haghparast@iausr.ac.ir
}

\begin{abstract}
Mobile banking is considered a breakthrough for banks and financial institutes since it allows them to provide distance banking service. However, many customers still doubt mobile banking security. In the present study, technology approval was developed and perceived risk, social trust and image were combined into classic TAM model in order to determine what factors influence on the acceptance of mobile banking applications from customers. The TAM model, first developed by Davis and his colleagues, was validated using collected from questionnaires and structural equation modeling (SEM). Results showed that personal attitude is a determinant factor of mobile banking acceptance. Usefulness and perceived risk can directly improve the use of mobile banking applications. In conclusion, our study showed that appropriate management and recognition of certain strategies are essential for improving new businesses which involve modern technological breakthroughs.
\end{abstract}

Keywords: Information Technology; Mobile Banking; Application; style; Intention of use; Mellat bank

\section{Introduction}

Banking system is the first structure which is affected by information technology and as a factor for integrating and expanding its range of influence, bases its activities on the updated technology of the world. Therefore, in order to attract more customers and diversify their services, banks have synchronized themselves with new information and communication technologies and their revolutions. In this regard, they have made structural changes in receiving and paying money and facilitating customer service (Joseph et al., 2009). Mobile banking is one of the approaches to financial services through information and communication technology that provides the possibility of a widespread choice of mobile telephone services in low-income countries (Anderson, 2010). Applications and programs that are easy to use attract consumers to use them. In addition, there is a positive and significant relationship between expectation of effort and ease of use and ultimately, directly affects the consumers' perception of the usefulness of the application by the users who use them (Hew et al., 2015). Perceived compatibility has a stronger effect on behavioral intention. On the other hand, credibility, performance expectations, expectations of effort and social influence have been significantly

Received (February 15, 2018), Review Result (May 11, 2018), Accepted (May 19, 2018)

* Corresponding Author 
influenced by the attitude of mobile banking sector which, in its turn, considerably influences the behavioral intention (Harrison, 2015).

The advantage of online banking and mobile applications in terms of financial institutions is that they allow users to access their account at any time and place. Such Accessibility indicates a better advantage over traditional banks. Despite what is mentioned so far, the important and interesting thing is that a number of customers who operate online banking have not changed their expectations, as expected [30]. Indeed, mobile banking is a new way of delivering banking services and the banks can provide information and other services more easily o their customers through mobile devices [26]. Mobile banking is also available everywhere thus it leads to cost reduction and brings more comfort and peace for customers [28]. The other advantages of mobile banking include reduction of urban trips, reduction of air pollution and traffic [12]. Through mobile banking, banks are able to reduce the workloads in their branches, carry out working processes at a faster and more accurate at cost-effective level. Moreover, software systems can provide instantaneous and up-to-date statistics to bank decision makers. Moreover, mobile banking provides the possibility of using bank services at any time and place; thus, mobile banking can lead to stronger relationships between customers and banks [24]. In order to investigate the effective factors on the intention of using mobile banking, a conceptual model has been proposed that includes the main variables determining the relationship with the user's behavior concerning the adoption of new technology in online banking. Using TAM model as a framework and develop it, this paper seeks to find the behavior of mobile banking users through relationships between different variables such as social image, usefulness, trust, intent to adopt technology, and so on. The relation between these variables will be explained in next Section. This paper is organized as follow; Section 2 includes the literature review, Section 3 identifies the effective factors, in Section 4, the conceptual framework is presented. Section 5 presents the methodology, Section 6 includes data analysis method and finally Section 7 explains the main findings. Conclusion of the paper is provided in Section 8.

\section{Literature Review and Theoretical Framework of the Study}

Previous studies show that effective factors in accepting mobile banking services include easy accessibility to offered services regardless of time and place, maintenance of privacy and time-saving [23]. Alalwan et al., [7] examined the effective factors on acceptance of mobile banking by Jordan Bank customers. The results showed that mainly behavioral intention has positive and significant effect on performance expectations, expectation of effort, motivation, cost value and trust.

Tseng et al., [34] examined the effect of the intention by using mobile banking. The results showed that mechanism of protecting the privacy of individuals is important in protecting the privacy of personal information and their intention to use mobile banking. In other words, it was found that enablement of privacy is important and led to the use of mobile banking by customers Hanafizadeh et al., [19] reviewed the acceptance of mobile banking by Iranian banks customers. The factors considered in this study are the utility, ease of use, demand for interaction, risk, and cost, compatibility with lifestyle, credibility and trust. In this study, the most influential factor was lifestyle and then trust. $\mathrm{Yu}$ [34] reviewed the factors affecting the acceptance of banking in Taiwan. He used the theory of integrated acceptance and the use of technology for review. The factors, whose effects were investigated in this study, are: expected performance, expected effort, social impact, facilitating conditions, perceived validity, perceived financial fee and perceived personal ability. Among these factors, the impacts of perceived personal ability and expected effort on the use of mobile banking were not confirmed. Studying the willingness to accept mobile banking in young people combined with TAM model with the advantages and risks of banking acceptance, Akturan et al., [5] concluded 
that the perceived use, social risk, performance risk and perceived advantages directly have considerable effect on the attitude of individuals; moreover, attitude is directly effective on the intention of its usage. In addition, no direct relation was observed between the perceived usefulness and the intention to use, between ease of use and attitude, as well as between financial risk, time risk, security risk, privacy, and attitude.

\section{The Identified Defective Factors}

In this section, we will discuss the Identified Defective Factors. These factors are such as mobile banking, Perceived Convenience, Perceived usefulness, Social image and so on. These parameters are essential to deal with the mobile banking problem.

\subsection{Mobile Banking}

Performing banking operation through mobile devices such as mobile phone or personal digital devices is called mobile banking. It is a new method to access banking services through the channel whereby the customer has interaction with bank with a mobile device [17]. Through mobile banking, customers could access to bank accounts and financial services [28]. Maintaining the Integrity of the Specifications.

\subsection{Perceived Convenience}

Convenience has been defined as the rate at which the individual believes the use of a special system doesn't require much effort based on physical or mental effort and learning. Moreover, perceived convenience is the level at which the mobile banking is perceived as an easy method for perception and performance [19].

\subsection{Perceived Usefulness}

Perceived usefulness is the degree at which the individual believes the use of a certain system promotes his occupational performance in organization [31].

\subsection{Social Image}

Using the According to Goffman theory (1967), social image of a social value is desired which each individual creates through interaction with others. In this study, social image is important since innovation could help the users on unreliability about consumption consequences; thus, the users might decide to use others' opinion for consultation and personal experiences. Social image is along with factors such as respect, honor, status, reputation, credit, competency, social relation, loyalty, trust, feeling of honor/ shame and etc., [9]. Thus, social image is able to affect the easy use of advanced mobile services [27].

\subsection{Perceived Advantages}

Perceived advantage of mobile banking is evaluation of emotional knowledge regarding the advantages and benefits related to its services. The perceived advantage is consumers' evaluation of the products' value; this value is based on the comparison of products' benefits for customer against the cost expend [5].

\subsection{Perceived Risk}

Gupta et al., [16] believe that the perceived risk as the customers' perception of uncertainty and consequences due to transaction with seller. The perceived risk is a multifaceted structure made of various factors including risk associated with innovation, purchase or special service [6]. 


\section{Conceptual Model}

The acceptance of Technology Model (TAM) is one of the most influential alternate designing methods for user acceptance of new information technology and systems. TAM was presented by Davis [10] and Davis et al., [11], which is based on Fishbein and Ajzen [13] theory, which is a rational theory of action (TRA). In this theory, in general, the construct of behavioral intention is related to two other structures; i.e., the attitude and the subjective norm. The aim of adopting TRA is that it can explain the technology acceptance factors that are generally able to explain the behavior of the user in a wide range of technologies. While, for end users and all users in any time, it is theoretically justified as being economic. Figure 1 presents the proposed model.

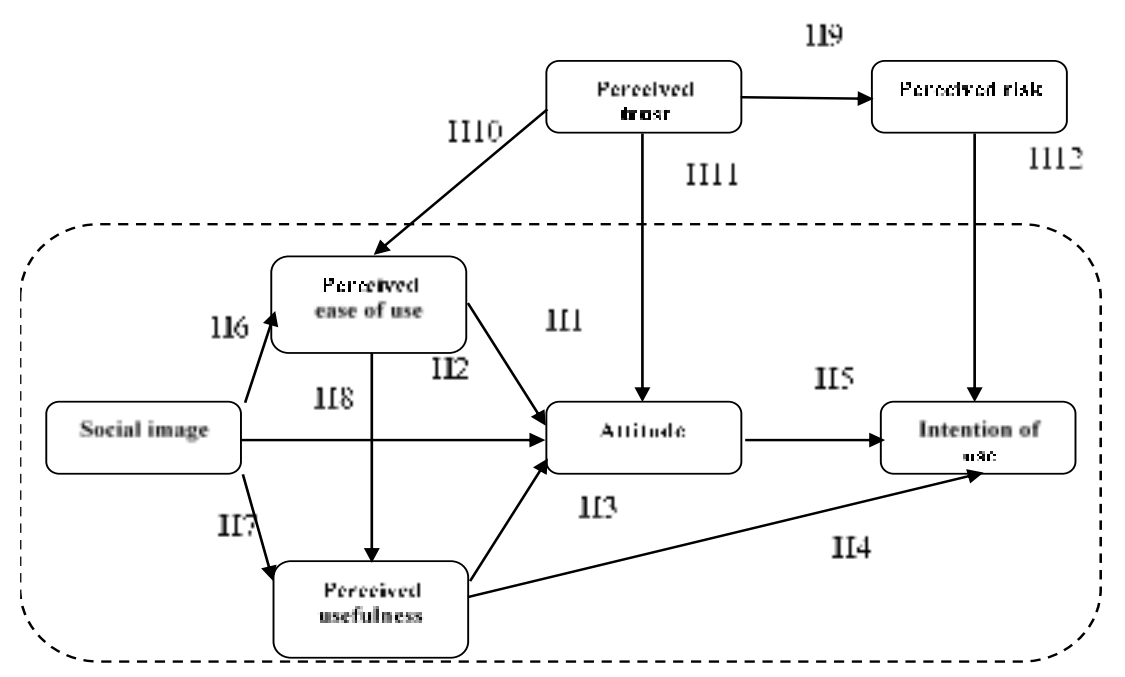

Figure 1. The Conceptual Model of Research

Considering the conceptual model of the study, the following assumptions are considered for the study of the subject:

H1: The ease of use of the applications provided by mobile banking has positive effect on users' attitudes.

H2: The ease of use of mobile banking programs has a positive impact on usefulness.

H3: Perceived usefulness has a positive effect on users' attitudes towards mobile banking programs and applications.

H4: Perceived usefulness has a positive impact on the intention to use of mobile banking applications.

H5: The people's attitude toward using mobile banking programs has a positive effect on the intention to use it.

H6: Social image has a positive effect on the ease of use of mobile banking applications.

H7: Social image has a positive impact on the usefulness of mobile banking applications.

H8: Social image has a positive effect on people's attitude towards mobile banking applications. 
H9: Perceived trust in mobile banking applications has a positive impact on the user's perceived risk.

H10: Perceived trust in mobile banking applications has a positive effect on its ease of use.

H11: Perceived trust in mobile banking applications has a positive impact on users' attitude.

H12: Perceived risk of mobile banking programs has a negative impact on users' intention to use.

\section{Research Methodology}

The main aim of this study is to investigate the effective factors on the intention of using mobile banking applications of Mellat Bank by development of a model and inspired from ATM. In following, the methods and instruments used for data collection, the validity and reliability investigation will be examined.

\subsection{Sample}

The selected samples in this study were customers of Mellat Bank of Tehran, provided that each of them has a mobile phone capable of installing related banking software as well as Internet connection features. In this research, the respondents are among all clients of Mellat Bank, Vali-e-Asr Branch, who use mobile bank application. The bank customers were selected through random sampling and the selection of customers of Mellat Bank has been done through random sampling such that in total 250 people participated in this study; out of which 200 questionnaires have been accepted and analyzed. Moreover, data of this study have been collected from April to May 2017.

\subsection{Questionnaire}

The questionnaire includes three parts. The first part includes the respondents' profile, which is related to the respondents' demographic characteristics (sex, education, age and income). The second part of questionnaire includes questions related to satisfaction and responsiveness of customers of Mellat mobile bank toward their needs and expectations, how long they are using mobile bank and how much they would like to use mobile bank for their banking work (results are presented in Table 1 and 2). The third part of the questionnaire measures research variables of the research consisted of 23 questions for which five-point Likert scale has been used varying from very low (1) and very high (5).

Table 1. Sample Statistics

\begin{tabular}{|c|c|c|c|}
\hline Item & Percentage & Item & Percentage \\
\hline \multicolumn{2}{|l|}{ Gender } & \multicolumn{2}{|l|}{ Employment status } \\
\hline Female & $0.87 \%$ & Student & $15.5 \%$ \\
\hline Male & $113 \%$ & Employee of private sector & $43.5 \%$ \\
\hline \multicolumn{2}{|l|}{ Age } & Employee of public sector & $22 \%$ \\
\hline Less than 30 years & $35 \%$ & Self-employment & $15.5 \%$ \\
\hline Between 30-40 & $45 \%$ & Housewife & $3.5 \%$ \\
\hline Between 40-50 & $17 \%$ & \multicolumn{2}{|l|}{ Income status } \\
\hline Above 50 years & $3 \%$ & Less than $5,000,000$ IRR & $11 \%$ \\
\hline \multicolumn{2}{|l|}{ Education } & Between $5000,000-10,000,000$ & $8.5 \%$ \\
\hline Associate degree & $12.5 \%$ & $10,000,000-15,000,000$ & $17 \%$ \\
\hline Bachelor of arts & $39.5 \%$ & Above $15,000,000$ & $63.5 \%$ \\
\hline Master of Arts & $46.5 \%$ & PhD and higher & $1.5 \%$ \\
\hline
\end{tabular}


Table 2. Descriptive Statistics

\begin{tabular}{|c|c|c|c|}
\hline Item & Percentage & Item & Percentage \\
\hline \multicolumn{2}{|c|}{ Duration of using Mobile bank services } & \multicolumn{2}{|c|}{$\begin{array}{l}\text { Satisfaction from transferring money to } \\
\text { card and deposit }\end{array}$} \\
\hline Less than 1 month & $31 \%$ & Very low & $7 \%$ \\
\hline Between 1-6 months & $12 \%$ & Low & $9.5 \%$ \\
\hline Between 6-12 months & $6.5 \%$ & Average & $37.5 \%$ \\
\hline Above 1 year & $50.5 \%$ & High & $25 \%$ \\
\hline \multicolumn{2}{|c|}{ Satisfaction from mobile bank } & Very high & $21 \%$ \\
\hline Very low & $8 \%$ & \multicolumn{2}{|c|}{ Satisfaction from bill payment } \\
\hline Low & $6 \%$ & Very low & $5.5 \%$ \\
\hline Average & $33.5 \%$ & Low & $12 \%$ \\
\hline High & $35.5 \%$ & Average & $34.5 \%$ \\
\hline Very high & $17 \%$ & High & $25.5 \%$ \\
\hline \multicolumn{2}{|c|}{ Banking work rate with mobile } & Very high & $22.5 \%$ \\
\hline Very low & $4.5 \%$ & \multicolumn{2}{|c|}{$\begin{array}{l}\text { Satisfaction of purchase facilities of } \\
\text { credited CIM card }\end{array}$} \\
\hline Low & $3.5 \%$ & Very low & $12 \%$ \\
\hline Average & $13.5 \%$ & Low & $12 \%$ \\
\hline High & $26.5 \%$ & Average & $31 \%$ \\
\hline Very high & $52 \%$ & High & $24 \%$ \\
\hline \multicolumn{2}{|c|}{$\begin{array}{l}\text { Responsive of mobile bank to needs and } \\
\text { expectations }\end{array}$} & Very high & $21 \%$ \\
\hline Very low & $6 \%$ & \multicolumn{2}{|c|}{$\begin{array}{l}\text { Satisfaction of facilities on receipt and } \\
\text { observation of last status of card and } \\
\text { account }\end{array}$} \\
\hline Low & $6.5 \%$ & Very low & $7.5 \%$ \\
\hline Average & $32.5 \%$ & Low & $14 \%$ \\
\hline High & $38 \%$ & Average & $35 \%$ \\
\hline \multirow[t]{2}{*}{ Very high } & $17 \%$ & High & 24.5 \\
\hline & & Very high & $19 \%$ \\
\hline \multicolumn{4}{|c|}{ Satisfaction of facilities of Mellat mobile banking } \\
\hline Very low & $6.5 \%$ & Low & $7.5 \%$ \\
\hline Average & $31.5 \%$ & High & $37.5 \%$ \\
\hline Very high & $17 \%$ & & \\
\hline
\end{tabular}




\subsection{Validity and Reliability}

Validity means that scale and content of scale or the questions included in the scale exactly evaluates the variables and studied subject such that the collected data are not extra to the study and also that part of required data concerning variable measurement is not eliminated from the content. Or in other words, it shows the reality [2]. The questionnaire used in this study has been extracted from the conceptual model of the research. Concerning relatively much work that has been done in terms of time on the indices and the manner of proposing questions of this study and also concerning the cooperation of the supervisor, the validity of mentioned questionnaire is confirmed. In the next stage, in order to determine the reliability of questionnaire, Cronbach's Alpha was used which confirmed up to $0.852 \%$ of the reliability of the questionnaire. Moreover, Cronbach's alpha percentage of each variable showed that the questionnaire has appropriate reliability. The structural reliability coefficient or combined reliability (CR) and average extracted variance (AVE) of each structure shows that the scale benefits from appropriate reliability. These indices measure the converging validity of research that confirms that high validity of structures. AVE measures the extracted variance by indices concerning measurement error. The value of this coefficient varies from 0 to 1 and the higher values than 0.05 are accepted [14]. Moreover, in combined reliability, when Goldstein and Dillon P value is bigger than 0.7, that block is uni-dimensional [1]. Moreover, if value of Cronbach's alpha, CR and AVE are respectively more than 0.6, 0.7 and 0.5 show that the structures benefit from appropriate reliability [14]. The results of calculations related to CR and AVE are presented in Table 3.

Table 3. The Results of Reliability and Validity Tests

\begin{tabular}{|l|l|l|l|}
\hline & \multicolumn{1}{|c|}{$\begin{array}{c}\text { Cronbach's } \\
\text { alpha }\end{array}$} & Combined Reliability & AVE \\
\hline Perceived ease of use & 0.819 & 0.892 & 0.736 \\
\hline Perceived usefulness & 0.910 & 0.943 & 0.848 \\
\hline Attitude & 0.888 & 0.930 & 0.817 \\
\hline The intention for use & 0.801 & 0.881 & 0.713 \\
\hline Social image & 0.900 & 0.937 & 0.833 \\
\hline Perceived trust & 0.923 & 0.951 & 0.867 \\
\hline Perceived risk & 0.723 & 0.878 & 0.782 \\
\hline
\end{tabular}

The divergent credit of questionnaire had been confirmed using the examination of correlation values between various variables indices in covariance matrix in Smart PLS output (Figure 2). In investigating Fornell-Larcker criterion, it is shown that the values in the main diameter of matrix (second root of explained variance values (AVE)) are bigger than all values in related low and column which indicates the correlation of indices with the dependent structure on them. 


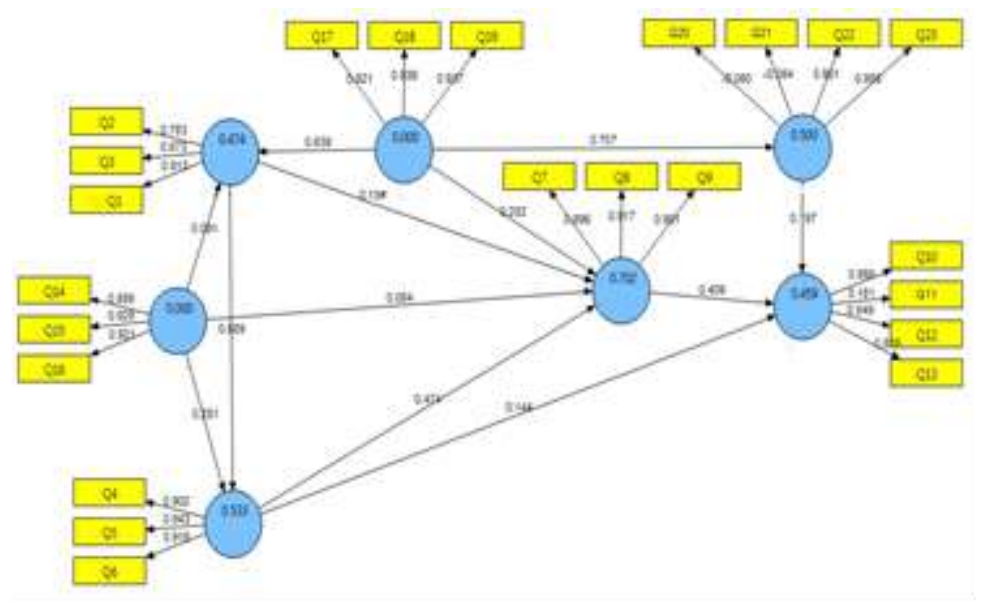

Figure 2. The Output of Initial Measurement Model in SmartPLC Software

Concerning the obtained results from the measured model in investigation of validity and reliability and the related explanations to acceptance threshold for mentioned indices, it is shown that by removing questions 11, 20 and 21 , it has good reliability and validity. Thus, we conclude that the model benefits from appropriate fitness. Thus, the final model has been able to explain appropriately the relation between questions describing variable. The model revision in this method will be done through trial and error with investigation of variation in validity indices level. These modifications will continue with removing inefficient measures until achieving validity indices to desired level. The final revised model is shown in Figure 3.

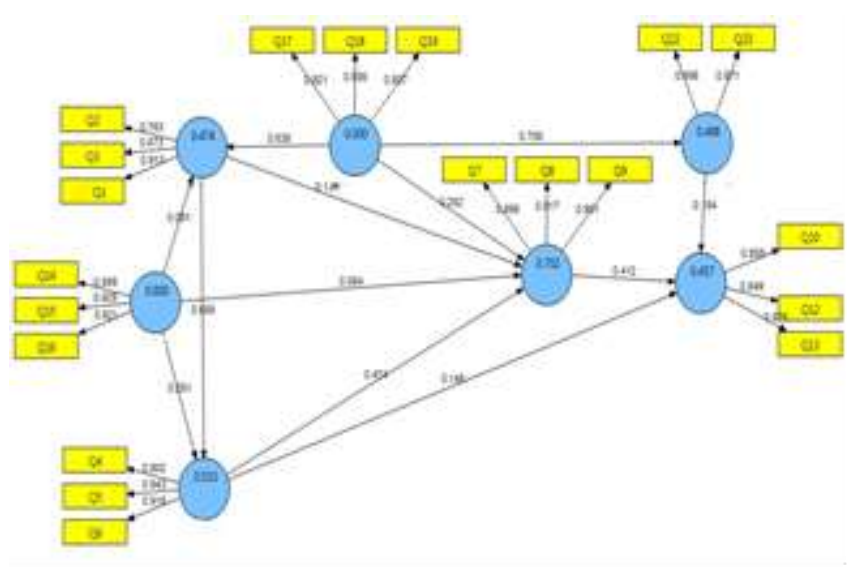

Figure 3. The Output of Final Measured Model in SmartPLC Software

\section{Data Analysis Method}

According to data analysis algorithm in PLS, after investigation of measured model fitness, it is time to fit the structural model. The structural model section has nothing to do with obvious variables despite measurement model; however, it just studies the hidden variables along with their relations. The structural model studies the relation between the structures. To this end, Bootstrapping function is used. The number of statistical sample in this study is 200 and about 1000 individuals have been considered as recommended in the Bootstrap test samples [18]. 


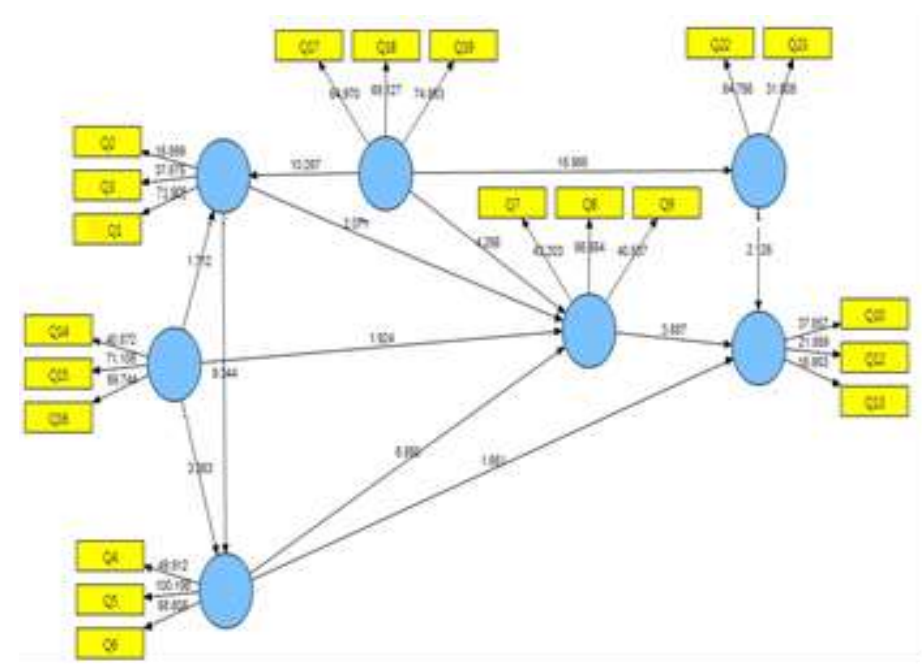

Figure 4. The Output of Structural Model in Smart PLC Software

The numerical value in relations indicates t-value statistics that is in fact the main criterion for confirmation or rejection of hypotheses. The accepted values for meaningfulness of path coefficients in reliability level 0.90, 0.95 and 0.99 should respectively be bigger than 1.64, 1.96 and 2.57 t-statistics (according to the [4]). Concerning these explanations, the main hypotheses for t-statistics is shown in Figure 4. Table 4 shows the results obtained from analysis of structural equations and the results of research hypotheses.

Table 3. The Results of Reliability and Validity Tests

\begin{tabular}{|l|l|l|l|l|}
\hline \multicolumn{1}{|c|}{ Hypothesis } & \multicolumn{1}{|c|}{ t-statistics } & \multicolumn{1}{c|}{$\begin{array}{c}\text { Path } \\
\text { coefficients }\end{array}$} & Reliability level & Result \\
\hline $1^{\text {st }}$ hypothesis & 2.071 & $0.134^{* *}$ & $0.95(\mathrm{p}<0.05)$ & Confirmed \\
\hline $2^{\text {nd }}$ hypothesis & 9.344 & $0.589^{* * *}$ & $0.99(\mathrm{p}<0.01)$ & Confirmed \\
\hline $3^{\text {rd }}$ hypothesis & 6.850 & $0.474^{* * *}$ & $0.99(\mathrm{p}<0.01)$ & Confirmed \\
\hline $4^{\text {th }}$ hypothesis & 1.551 & $0.148^{\text {ns }}$ & - & Rejected \\
\hline $5^{\text {th }}$ hypothesis & 3.887 & $0.412^{* * *}$ & $0.99(\mathrm{p}<0.01)$ & Confirmed \\
\hline $6^{\text {th }}$ hypothesis & 1.712 & $0.091^{*}$ & $0.90(\mathrm{p}<0.1)$ & Confirmed \\
\hline $7^{\text {th }}$ hypothesis & 3.383 & $0.251^{* * *}$ & $0.99(\mathrm{p}<0.01)$ & Confirmed \\
\hline $8^{\text {th }}$ hypothesis & 1.924 & $0.084^{*}$ & $0.90(\mathrm{p}<0.1)$ & Confirmed \\
\hline $9^{\text {th }}$ hypothesis & 15.986 & $0.706^{* * *}$ & $0.99(\mathrm{p}<0.01)$ & Confirmed \\
\hline $10^{\text {th }}$ hypothesis & 10.267 & $0.638^{* * *}$ & $0.95(\mathrm{p}<0.05)$ & Confirmed \\
\hline $11^{\text {th }}$ hypothesis & 4.258 & $0.282^{* * *}$ & $0.99(\mathrm{p}<0.01)$ & Confirmed \\
\hline $12^{\text {th }}$ hypothesis & 2.126 & 0.184 & - & Rejected \\
\hline
\end{tabular}

\section{Results}

The first criterion for investigation of the fitness of structural model in a study is R2 coefficients for hidden dependent variables (endogenous). R2 indicates the effect of a dependent variable on an independent variable. Three values of $0.19,0.33$ and 0.67 are considered as the criteria values for weak, average and strong R2 values [3]. Concerning independent variable of intention of use, it could be said that $46 \%$ of variations of intention of use is defined by variation in risk, attitude and usefulness variables. Concerning the independent variable of attitude of users, it could be said that $70 \%$ of 
variations of users' attitude variable is defined by variation in usefulness, ease of use, social image and perceived trust variables. Moreover, the results of study showed that the perceived usefulness has no effect on the intention to use of mobile banking programs. No negative effect was found on the perceived risk of mobile banking programs in respect to the intention of users to use mobile banking. In fact, it could be said that the experience in using this application improves the intention to use that is considered by the user as a technology of low risk and without determining factor in its approval. According to users, the ease of use of mobile banking, accessibility, ease of banking operation including payment and transfer by mobile phone has a positive effect on their attitude toward the intention to use mobile banking. From various factors related to social image, usefulness (3.383), it has the highest effect compared to ease of use (1.712) and attitude (1.924). Moreover, the factors related to perceived trust on the perceived risk $(15,986)$, ease of use $(10,267)$ and attitude $(4,258)$ that shows that perceived trust is a main factor on acceptance of a new technology that could greatly influence the users. According to respondents, the perceived trust includes bank honesty, fulfillment of commitments of bank toward customer and etc. that have positive effect on the individuals' attitude toward using mobile banking. In investigation of negative effect of perceived risk on the intention of use of customers, it was specified that the perceived risk $(2,126)$ has no negative effect on the intention of use of mobile banking by customers. Acceptance perception or perception of such cases is very significant in determining a strategy for attraction of new users. Perception of acceptance or acceptance of such items is significant in determining a strategy for attraction of new users. The banks should expand their communicative measures to explain the benefits of using this type of programs of mobile phone and create usefulness for users. The results showed that the individuals' incline and attitude is determining factor in using mobile banking and the perceived usefulness and risk which directly influence the users, improve this program. Finally, the study showed that the main consequences of management and identification of special strategies for enhancement of new business in new technologic advancement are required and necessary.

\section{Conclusion}

In this article we showed that, the ease of use of the applications provided by mobile banking has positive effect on users' attitudes, The ease of use of mobile banking programs has a positive impact on usefulness, Perceived usefulness has a positive effect on users' attitudes towards mobile banking programs and application, Perceived usefulness has a positive impact on the intention to use of mobile banking applications, The people's attitude toward using mobile banking programs has a positive effect on the intention to use it, social image has a positive effect on the ease of use of mobile banking applications, social image has a positive impact on the usefulness of mobile banking applications, social image has a positive effect on people's attitude towards mobile banking applications, perceived trust in mobile banking applications has a positive impact on the user's perceived risk, perceived trust in mobile banking applications has a positive effect on its ease of use, perceived trust in mobile banking applications has a positive impact on users' attitude and perceived risk of mobile banking programs has a negative impact on users' intention to use.

\section{References}

[1] A. Azar, "Route-Structural Modeling in Management: The Application of Smart-PLS Software", Tehran: Negah Danesh, (1391).

[2] M. Reza Hefeznia, "An Introduction to the Research Method in the Humanities", Samt Publication, 10th print, (1384).

[3] A. Davari and A. Rezazadeh, "Structural Equations Modeling with PLS Software", 2nd print, Jahad Daneshgahi Publication, Tehran, (1393). 
[4] S. Mohsenin and M. Rahim, "Structural Equations based on Partial Least Square Approch with SmartPLS Software", 1st print. Ketab Mehraban Publication, Tehran, (1393).

[5] U. Akturan and N. Tezcan, "Mobile banking adoption of the youth market: Perceptions and intentions", Marketing Intelligence \& Planning, vol. 20, no. 4, (2012), pp. 444-459.

[6] J. Aldás, C. Lassala, C. Ruiz and S. Sanz, "Análisis de los fac-tores determinantes de la lealtad hacia los servicios bancarios", Cuadernos de Economía y Dirección de la Empresa, vol. 14, (2011), pp. 26-39.

[7] A. A. Alalwan, Y. K. Dwivedi and N. P. Rana, "Factors influencing adoption of mobile banking by Jordanian bank customers: Extending UTAUT2 with trust", International Journal of Information Management, vol. 37, no. 3, (2017), pp. 99-110.

[8] J. Anderson, "M-banking in developing markets: competitive and regulatory implications", Info, vol. 12, no. 1 , pp. 18-25.

[9] Y. Bao, K. Z. Zhou and C. Su, "Face consciousness and risk aversion: do they affect consumer decision-making?", Psychology \& Marketing, vol. 20, no. 8, (2003), pp. 733-755.

[10] F. D. Davis, "Perceived usefulness, perceived ease of use, and user acceptance of information technology”, MIS Quarterly, vol. 13, no. 3, (1989), pp. 319-340.

[11] F. D. Davis, R. P. Bagozzi and P. R. Warshaw, "User acceptance of computer technology: a comparison of two theoretical models", Management Science, vol. 35, no. 8, (1989), pp. 982-1003.

[12] M. Esfidani, F. Akbari and M. Davari, "Mobile Banking in Iran, challenges and barriers, offering solution based on Technology Acceptance Model (TAM)", The 4nd National Conference on Electronic Commerce. Tehran: Commerce ministry, Assistance planning and economic affairs. (in Persian), (2007).

[13] M. Fishbein and I. Ajzen, "Belief, Attitude, Intention, and Behavior: an Introduction to Theory and Research", Addison-Wesley, Reading, MA, (1975).

[14] C. Fornell and D. F. Larcker, "Evaluating structural equation models with unobservable variables and measurement error", Journal of marketing research, pp. 39-50.

[15] E. Goffman, "Interaction ritual", New York: Pantheon, (1967).

[16] S. Gupta and H. W. Kim, "Value-driven Internet shopping: Themental accounting theory perspective", Psychology \& Marketing, vol. 27, no. 1, (2010), pp. 13-35.

[17] J. Gu, S. C. Lee and Y. H. Suh, "Determinants of behavioral intention to mobile bank", Expert Systems with Applications, vol. 36, no. 9, (2009), pp. 11605-11616.

[18] J. F. Hair Jr, G. T. M. Hult, C. Ringle and M. Sarstedt, "A Primer on Partial Least Squares Structural Equation Modeling (PLS-SEM)", SAGE Publications, (2013).

[19] P. Hanafizadeh, M. Behboudi, A. A. Koshksaray and M. J. S. Tabar, "Mobile-banking adoption by Iranian bank clients", Telematics and Informatics, vol. 31, no. 1, (2014), pp. 62-78.

[20] D. Harrison, "Mobile banking acceptance among young con-sumers in Germany: An empirical analysis", (Doctoral dissertation, BI Norwegian Business School), (2015).

[21] J. J. Hew, V. H. Lee, K. B. Ooi and J. Wei, "What catalysesmobile apps usage intention: An empirical analysis", Industrial Management \& Data Systems, vol. 115, no. 7, (2015), pp. 1269-1291.

[22] M. Joseph, Y. Sekhon, G. Stone and J. Tinson, "A ranking of importance of selected technology on consumer perception of service delivery performance", International Journal of American Academy of Business, vol. 11, no. 4, (2009), pp. 210-213.

[23] T. Laukkanen, "Customer preferred channel attributes in multi-channel electronic banking", International Journal of Retail and Distribution Management, vol. 35, no. 5, (2007), pp. 393-412.

[24] T. Laukkanen, "Internet vs mobile banking: comparing customer value perceptions", Business Process Management Journal, vol. 13, no. 6, (2007), pp. 788-797.

[25] H. F. Lin, "An empirical investigation of mobile banking adoption: The effect of innovation attributes and knowledge-based trust", International Journal of Information Management, vol. 31, no. 3, (2011), pp. 252-260.

[26] H. F. Lin, "Determining the relative importance of mobile banking quality factors", Computer Standards \& Interfaces, vol. 35, no. 2, (2012), pp. 195-204.

[27] C. López-Nicolás, F. J. Molina-Castillo and H. Bouwman, "An assessment of advanced mobile services acceptance: Con-tributions from TAM and diffusion theory models", Information \&Management, vol. 45, (2008), pp. 359-364.

[28] X. Lou, H. Li, J. Zhang and J. P. Shim, "Examining multi-dimensional trust and multi-faceted risk in initial acceptance of emerging technologies: An empirical study of mobile banking services", Decision Support Systems, vol. 49, no. 2, (2010), pp. 222-234

[29] H. Mohammadi, "A study of mobile banking loyalty in Iran", Computers in Human Behavior, vol. 44, (2015), pp. 35-47.

[30] F. Mũnoz-Leiva, J. Sánchez-Fernández and T. Luque-Martínez, "How to improve trust toward electronic banking", OnlineInformation Review, vol. 34, no. 6, (2010), pp. 907-934.

[31] T. Ramayah and M.-C. Lo, "Impact of shared beliefs on "perceived usefulness" and "ease of use" in the implementation of an enterprise resource planning system", Management Research News, vol. 30, no. 6, (2007), pp. 420-431.

[32] F. F. Reichheld and P. Schefter, "E-loyalty: Your secret weaponon the web", Harvard Business Review, vol. 78, no. 4, (2000), pp. 105-113. 
[33] J. T. Tseng, H. L. Han, Y. H. Su and Y. W. Fan, "The Influence of Intention to Use the Mobile BankingThe Privacy Mechanism Perspective", Journal of Management Research, vol. 9, no. 1, (2017), pp. 117137.

[34] C.-S. Yu, "Factors affecting individuals to adopt mobile banking: empirical evidence from the UTAUT Model", Journal of Electronic Commerce Research, vol. 13, no. 2, (2012), pp. 104-121.

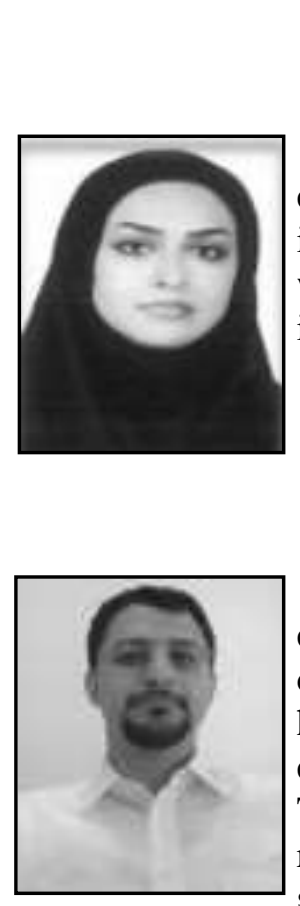

\section{Authors}

Shirin Krarmi, received his B.Sc. in computer software engineering in 2012. She received her M.Sc. degrees in e-commerce information Technology in 2017. Since 2007, he has been worked with Ista Co., Valiasre Street, Tehran, Iran. His research interests include computer Networking.

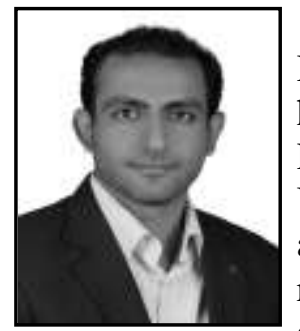

Majid Haghparast, received his B.Sc. in computer hardware engineering in 2003. He received his M.Sc. and Ph.D. degrees in computer architecture in 2006 and 2009, respectively. Since 2007, he has been affiliated with the Computer Engineering Faculty, Yadegare-Imam Khomeini (RAH) Shahre Rey Branch, IAU University, Tehran, Iran. His research interests include computer arithmetic and reversible logic circuits. Since April 2017 he is conducting his sabbatical at the Johannes Kepler University Linz, Austria, where he also is a Research Fellow. Dr. Haghparast is on the panel of reviewers for various international journals.

Mohsen Gharakhani, is Assistant Professor and Chair of the Department of Accounting and Finance at Iranian University, where he has been since 2016. From 2012 to 2016, he served as Assistant Professor and Head of Industrial Engineering Department at Qom University. He received a B.S. from Tehran Polytechnic in 2007, and an M.S. from the Sharif University of Technology in 2009. He received his Ph.D. in Industrial Engineering from the Iran University of Science and Technology in 2012. From 2005 to 2007, he worked at National Iranian Petrochemical Company (NIPC) in Tehran, eventually as a Senior Business Analyst. His research interests span both Industrial Engineering and Finance. Much of his work has been on improving the understanding, optimizing, and performance analysis of portfolio problem, mainly through the application of data mining, statistics, and robust optimization. In the Financial area, he has worked on portfolio selection, CAPM model and utility theory. He has explored application of robust optimization in many real life decision-making problems. As of 2018, Google Scholar reports over 250 citations to his works. He has given numerous invited talks and tutorials, and book authorship. Dr. Gharakhani is an editorial board of journal of Decision Science Letters at Growing Science Pub and cooperate as invited reviewer in many international journals and conferences. 